\title{
rolA locus of the Ri plasmid directs developmental abnormalities in transgenic tobacco plants
}

\author{
Vilas P. Sinkar, Francois Pythoud, ${ }^{1}$ Frank F. White, ${ }^{2}$ Eugene W. Nester, ${ }^{1}$ and Milton P. Gordon ${ }^{3}$ \\ Department of Biochemistry and 'Department of Microbiology, University of Washington, Seattle, Washington 98195 USA; \\ ${ }^{2}$ Department of Plant Pathology, Kansas State University, Manhattan, Kansas 66506 USA
}

Plants containing the left T-DNA ( $\left.T_{L}\right)$ of Agrobacterium rhizogenes show a variety of developmental abnormalities that include severely wrinkled leaves, loss of apical dominance, reduced geotropism of roots, reduced internode distances, and floral hyperstyly. The $T_{L}$-DNA also affects the morphology of tumor tissue at the site of inoculation on Kalanchoe diagremontiana leaves. Single mutations at four loci of the $T_{\mathfrak{L}}-\mathrm{DNA}$ (rolA, rolB, rolC, and rolD) are known to affect tumor morphology on $K$. diagremontiana leaves. We regenerated plants from tissues transformed with $T_{L}$-DNA containing mutations in each of the rol loci in order to determine which of the rol loci, if any, control the abnormal plant phenotype. Only plants regenerated after infection with bacteria containing a mutation in rolA locus showed loss of the wrinkled leaf phenotype. The rolA locus was cloned into the plant transformation vector pGA472 and introduced alone into plants. Transgenic plants containing rolA displayed the abnormal phenotype. These results indicate that rolA is the primary determinant of the severely wrinkled phenotype of Ri plasmid transgenic plants. Other rol loci may influence the degree of developmental abnormalities.

[Key Words: Agrobacterium rhizogenes; Ri plasmid; $\mathrm{T}_{\mathrm{L}}$-DNA, rolA locus; developmental abnormalities]

Received November 23, 1987; revised version accepted April 18, 1988.

Agrobacterium rhizogenes incites tumor formation on many plants (De Cleene and De Ley 1981; Trulson et al. 1986; Pythoud et al. 1987; Spano et al. 1987). These tumors are characterized on a large number of plant species by initial callus formation and subsequent extensive root proliferation. The induction of callus and root proliferation by $A$. rhizogenes is dependent on the root-inducing (Ri) plasmid (Moore et al. 1979; White and Nester 1980), a portion of which is transferred and stably integrated into the host plant genome /Chilton et al. 1982; White et al. 1982; Willmitzer et al. 1982; for recent reviews, see Sinkar et al. 1987; White and Sinkar 1987). The $\mathrm{Ri}$ plasmid present in the agropine-type strain A4 contains two transferred DNA (T-DNA) regions, and although these regions have not been characterized to the extent of the closely related tumor-inducing (Ti) plasmid of Agrobacterium tumefaciens, the $\mathrm{Ri}$ T-DNA appears to share many structural features with the Ti T-DNA (Huffman et al. 1984; White et al. 1985). T-DNA transfer from $A$. rhizogenes to plant cells is probably directed by border sequences flanking the $T$ DNAs similar to $\mathrm{Ti}$ T-DNA borders (Slightom et al. 1986), and hybridization and complementation experiments indicate that $\mathrm{Ri}$ plasmids contain most of the nontransferred virulence (vir) genes (Huffman et al. 1984). Genes present on the two T-DNA regions are transcribed as polyadenylated mRNA when incorpo-

${ }^{3}$ Corresponding author. rated into plant nuclear DNA (Durand-Tardif et al. 1985; Taylor et al. 1985a; Ooms et al. 1986b; Sinkar et al. 1988).

The right $T$-DNA region $\left(T_{R}-D N A\right)$ of the $\mathrm{Ri}$ plasmid contains the genes involved in the biosynthesis of indole acetic acid (IAA), a plant hormone, and are referred to as tms 1 and $t m s 2$ /also referred to as aux 1 and aux2, respectively). These genes show extensive homology with the tms region of the $\mathrm{Ti}$ plasmid and can be complemented interspecifically (Huffman et al. 1984; Jouanin 1984; White et al. 1985; Offringa et al. 1986). The $T_{R}$-DNA also contains the genes for the synthesis of agropine (Huffman et al. 1984; Jouanin 1984; De Paolis et al. 1984). The nucleotide sequence has been determined for the entire $T_{L}$-DNA. A total of 18 open reading frames (ORFs), of 255 nucleotides or greater in length, have been identified (Slightom et al. 1986).

Both T-DNA regions participate in root induction, either individually or together, depending on the plant species or tissue (White et al. 1985; Vilaine and CasseDelbart 1987). Mutations in the tms 1 and $t m s 2$ genes severely attenuate the root induction response on tobacco stem (Nicotiana tabacum), basal carrot disks (Daucus carota), and $K$. diagremontiana leaves (Cardarelli et al. 1985; White et al. 1985; Boulanger et al. 1986; Vilaine and Casse-Delbart 1987). Four left T-DNA $\left(T_{L^{-}}\right.$ DNA) loci have been identified by transposon and deletion mutagenesis, which affects tumor morphology on $K$. diagremontiana leaves, and these loci have been ten- 
tatively assigned the names rolA, rolB, rolC, and rolD (White et al. 1985; Estramareix et al. 1986). The concerted action of both $T_{L}$-DNA and $T_{R}$-DNA in some circumstances is shown by the loss of root induction on $K$. diagremontiana leaves when either tmsl or rolB are inactivated (White et al. 1985). Bacteria that contain only the $T_{R}$-DNA are capable of inducing roots on $K$. diagremontiana and tobacco stems (White et al. 1985). Recently, bacteria containing $T_{\mathrm{L}}$-DNA alone have been shown to be capable of inducing root formation on some plant tissue explants and on apical sides of carrot disks (Vilaine and Casse-Delbart 1987; Vilaine et al. 1987). Thus, the Ri plasmid appears to contain multiple mechanisms that can function together or independently to induce root formation on plants.

Plants containing T-DNA can be regenerated from transformed tissues (Ackermann 1977, Spano and Costantino 1982; Costantino et al. 1984; David et al. 1984; Tepfer 1984; Ooms et al. 1985; Taylor et al. 1985b; Sinkar et al. 1987). Such transgenic plants often have developmental abnormalities that are consistently observed in a variety of plant species (Ackermann 1977; Tepfer 1984; Ooms et al. 1985; Taylor et al. 1985a; Sinkar et al. 1987). The transformed phenotype has been correlated with the presence of $\mathrm{T}_{\mathrm{L}}$-DNA (Durand-Tardif et al. 1985; Taylor et al. 1985a; Sinkar et al. 1987), or more precisely, the EcoRI fragment 15 (Cardarelli et al. 1987; Spena et al. 1987). Therefore, genes of the $T_{L}$-DNA also control the transformed phenotype, as well as morphological effects at primary inoculation sites. In an effort to determine whether the rol loci are also involved in the traits of the $T_{L}$-DNA containing plants, whole plants were regenerated from tissues transformed with $A$. rhizogenes containing mutations in the $\mathrm{T}_{\mathrm{L}}-\mathrm{DNA}$. This analysis indicated that the rolA locus is the principle locus controlling the severely wrinkled phenotype of transgenic plants. Furthermore, we introduced the rolA locus in plants and found that it alone is sufficient to cause developmental abnormalities in transgenic plants.

\section{Results}

\section{Experimental approach}

To assess involvement of the rol loci on transgenic plant morphology, a set of $T_{L}$-DNA transposon and deletion mutations covering the four rol loci were selected for plant transformation and regeneration experiments. However, before a set of transgenic plants was derived, a plant-selectable marker in the form of the chimeric kanamycin-resistance gene [eukaryotic kanamycin-resistance (EKR)] was introduced into the $T_{\mathrm{L}}$-DNA. Plants containing $T_{L}$-DNA were obtained by regenerating shoots from roots that appear after infection with bacteria. Although many of the roots developing after an infection by $A$. rhizogenes contain $\mathrm{T}_{\mathrm{L}}$-DNA, not every root necessarily contains it. Frequently, roots not containing $T_{L}$-DNA are induced by the auxin-synthesizing genes present in the $T_{R}$-DNA. In addition, the prospect that one or more of the mutations might lead to the loss of the $T_{\mathrm{L}}$-DNA-mediated root induction or might induce slow-growing abnormal roots was anticipated. Therefore, the EKR gene allowed selection of both abnormal and normal-appearing roots containing the $T_{L}$-DNA.

The EKR gene (containing the nopaline synthase promoter, the bacterial neomycin phosphotransferase structural gene, and nopaline synthase $3^{\prime}$ sequences) was derived from pMON128 as an EcoRI fragment (Fraley et al. 1983 ) and was cloned into the unique EcoRI site of pET33 (Stachel et al. 1985), a defective Tn3 bacterial transposon, giving TnMY903. The defective Tn3 also harbors the $\beta$-lactamase gene for resistance to carbenicillin and can transpose when transposase activity is supplied in trans. TnMY903 was introduced into a site on the Ri $T_{L}$-DNA where previous studies had indicated that an insertion would not disrupt $T_{L}$-DNA function, as determined by $K$. diagremontiana leaf inoculation tests. TnMY903 was first introduced into pFW302, a wide host-range cosmid containing the $T_{L}-D N A$. An insertion into the left portion of HindIII fragment 21 was selected and introduced by homologous recombination into the wild-type Ri plasmid and a set of $A$. rhizogenes strains harboring mutations in rolA, rolB, rolC, and rolD (Fig. 1). The resulting strains, R1500 (wild type), R1501 (rolA-), R1502 (rolB ${ }^{-}$), R1503 (rolC ${ }^{-}$), and R1504 (rolD ${ }^{-}$), were tested for the original mutant phenotype on $K$. diagremontiana leaf inoculations and were observed to produce symptoms characteristic of the rol mutation that they represent.

\section{Effects of rol mutations on transgenic plants}

R1500, R1501, R1502, R1503, and R1504 (Table 1) were used for in vitro leaf disk inoculations to derive a corresponding set of transformed root lines from $N$. tabacum var. xanthi. Roots were observed along the edges of the disks within 20 days. The roots were excised and placed on Murashige and Skoog medium without phytohormones containing kanamycin (Murashige and Skoog 1962) (MS ${ }^{-}$). Roots that grew well in the presence of 250 $\mu \mathrm{g} / \mathrm{ml}$ of kanamycin were selected for further study. Untransformed roots could not grow on media containing $>50 \mu \mathrm{g} / \mathrm{ml}$ of kanamycin. Transformed roots were cultured on $\mathrm{MS}^{-}$medium, and shoots that formed spontaneously upon subculture were transferred to fresh plates containing $\mathrm{MS}^{-}$medium and kanamycin. Plants that displayed well-developed shoot and root systems were transplanted into pots.

Plants obtained with R1500 displayed the typical features of $T_{L}$-DNA-containing plants. The leaves were highly wrinkled and small; plant height and internode distances were shortened; stems had increased spontaneous adventitious rooting; and plants had a bushier growth habit due to the loss of apical dominance when compared to normal tobacco plants cycled through tissue cultures (Fig. 2). These plants also displayed increased adventitious rooting, a decrease in root geotropic response, and floral hyperstyly (not shown). Plants obtained from infections with strains $\mathrm{R} 1502\left(\mathrm{rolB}^{-}\right)$, R1503 $\left(\right.$ rolC $\left.^{-}\right)$, and $\mathrm{R} 1504$ (rolD $\left.^{-}\right)$all exhibited the abnormal 


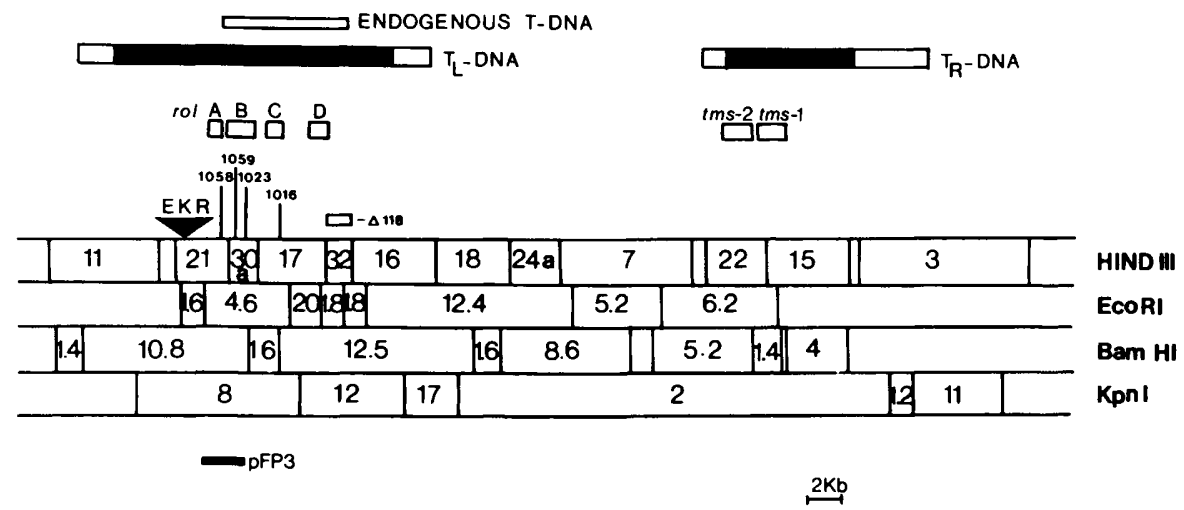

Figure 1. Restriction map of the T-DNA of pRiA4b. Positions of the rol loci, as identified by transposon mutations, are shown (White et al. 1985). Also shown are the positions of the tms1 and tms2 loci (Huffman et al. 1984) and the extent of endogenous T-DNA present in $N$. glauca (Furner et al. 1986). Tn5 insertions are indicated by vertical lines. ( $\mathbf{\nabla}$ ) Insertion of pNos-NPTII-poly(A) Nos (EKR gene) in the left side of $\mathrm{H}-21 ;(\square)$ deletion. Restriction fragment used to clone the rolA (pFp3) locus is also shown. (For more details on the insertion and deletion mutants used in the study, refer to Table 1.)

phenotype. However, plants containing the R1501 $\mathrm{T}_{\mathrm{L}}$ DNA $\left(\right.$ rolA $\left.{ }^{-}\right)$did not display the aberrant phenotype of $\mathrm{T}_{\mathrm{L}}$-DNA-containing plants. Particularly evident was the loss of the severely wrinkled leaf trait (see Fig. 3).

Although the plants containing $\mathrm{T}_{\mathrm{L}}$-DNA mutations (with the exception of those with rolA mutation) showed overall morphology similar to that displayed by plants containing wild type $T_{\mathrm{L}}$-DNA, some subtle morphological differences were observed. Similarly, plants containing $\mathrm{T}_{\mathrm{L}}$-DNA with mutation in rolA were not identical in morphology to untransformed plants regenerated from tissue cultures. Therefore, an attempt was made to quantitate some of the different growth behaviors of these plants to assess the contribution of various rol genes to the aberrant features. Measurements of height, leaf length-to-width ratio, flower size, and frequency of hyperstyly were taken from the different plants (Table 2). Although these data do not delineate

Table 1. Bacterial strains and plasmids used in this study

\begin{tabular}{|c|c|c|}
\hline Strains and plasmids & Relevant phenotype and genotype & Source \\
\hline \multicolumn{3}{|l|}{ Agrobacterium spp. } \\
\hline R1000 (pRiA4b) & Onc $^{+}$ & derivative of strain A4T (White and Nester 1980) \\
\hline R1058 (rolA $\left.{ }^{-}\right)$ & $\mathrm{Onc}^{+}, \mathrm{Kan}^{\mathrm{R}}$ & White et al. (1985) \\
\hline $\mathrm{R} 1059(\mathrm{rolB}-\mid$ & $\mathrm{Onc}^{+}, \mathrm{Kan}^{\mathrm{R}}$ & White et al. (1985) \\
\hline $\mathrm{R} 1023\left(\mathrm{rolB}^{-}\right)$ & $\mathrm{Onc}^{+}, \mathrm{Kan}^{R}$ & White et al. (1985) \\
\hline $\mathrm{R} 1016$ (rolC-) & $\mathrm{Onc}^{+}, \mathrm{Kan}^{\mathrm{R}}$ & White et al. (1985) \\
\hline $\mathrm{R} 1226\left(118\right.$, rolD $\left.^{-}\right)$ & $\mathrm{Onc}^{+}, \mathrm{Kan}^{\mathrm{R}}$ & White et al. (1985) \\
\hline R1500 (R1000 with EKR) & $\mathrm{Onc}^{+}, \mathrm{Carb}^{\mathrm{R}}$ & this study \\
\hline R1501 (R1058 with EKR) & $\mathrm{Onc}^{+}, \mathrm{Kan}^{\mathrm{R}}, \mathrm{Carb}^{\mathrm{R}}$ & this study \\
\hline R1502 (R1023 with EKR) & $\mathrm{Onc}^{+}, \mathrm{Kan}^{\mathrm{R}}, \mathrm{Carb}^{\mathrm{R}}$ & this study \\
\hline R1503 (R1016 with EKR) & $\mathrm{Onc}^{+}, \operatorname{Kan}^{\mathrm{R}}, \mathrm{Carb}^{\mathrm{R}}$ & this study \\
\hline R1504 (R1226 with EKR) & $\mathrm{Onc}^{+}, \mathrm{Kan}^{\mathrm{R}}, \mathrm{Carb}^{\mathrm{R}}$ & this study \\
\hline \multicolumn{3}{|l|}{ E. coli } \\
\hline $\mathrm{HB} 101$ & thr, leu, thi, pro & \\
\hline $\mathrm{C} 2110$ & pol, gyrA, NalR & Ditta et al. (1981) \\
\hline $2174(\mathrm{pPHljI})$ & met, pro, $\mathrm{Gn}^{\mathrm{R}}, \mathrm{RK} 2^{\text {rep }}$, IncPl & Beringer et al. (1978) \\
\hline HB101rif (pRK2073) & $\mathrm{Tra}^{+}$ & Leong et al. (1982) \\
\hline \multicolumn{3}{|l|}{ Plasmids } \\
\hline pFW302 & $\mathrm{Tc}^{\mathrm{R}}, \mathrm{RK} 2^{\mathrm{rep}}$, IncPl & $\begin{array}{l}\mathrm{H}-11 \text { to } \mathrm{H}-18 \text { of pRiA4b in pVK } 102 \\
\text { (White et al. } 1985 \text { ) }\end{array}$ \\
\hline pFW41 & $\mathrm{Tc}^{\mathrm{R}}, \mathrm{RK} 2^{\text {rep }}$, IncP1 & $\mathrm{H}-24 \mathrm{a}$ to $\mathrm{H}-3$ in pHK17 (Huffman et al. 1984) \\
\hline pMY903 & $\mathrm{Carb}^{\mathrm{R}}$ & $\begin{array}{l}\text { pNOS-NPTII-3'NOS (EKR) into pETW3, } \\
\text { (M. Yanofsky, unpubl.) }\end{array}$ \\
\hline pVS1 & Tet $^{R}$, Carb $^{\mathbf{R}}$ & EKR into $\mathrm{H}-21$ (this study) \\
\hline pGA472 & Tet $^{R}$ & $\begin{array}{l}\text { Ti plasmid-derived vector for plant transformation } \\
\text { (An et al. 1985) }\end{array}$ \\
\hline pFP3 & Tet $^{\mathrm{R}}$ & rolA into pGA 472 \\
\hline
\end{tabular}




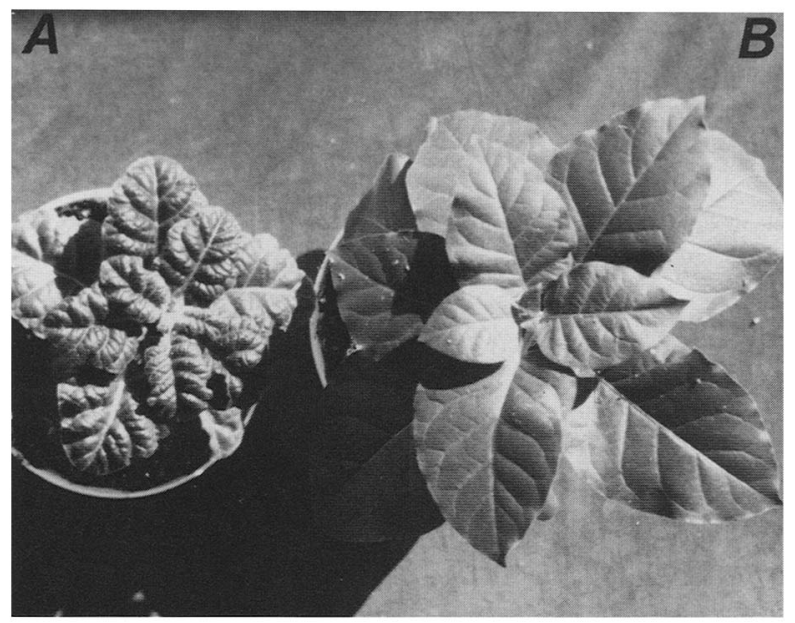

Figure 2. $N$. tabacum regenerates from tissue culture. (Plant $A$ ) Regenerated from R1500-transformed leaf tissue of $N$. tabacum. (Plant $B) N$. tabacum regenerated from nontransformed tissues.

clear differences between rol mutants, the results for plants with rolB $\mathrm{B}^{-}$and rolD ${ }^{-}$T-DNA suggest that these two genes may exert some control over the severity of abnormal phenotype in the presence of rolA. Plants with rol $\mathrm{C}^{-} \mathrm{T}_{\mathrm{L}}$-DNA were most similar in appearance to plants with wild-type T-DNA. On the other hand, rolA ${ }^{-}$ plants were not identical to the control plants regenerated from untransformed tissues. The rolA- plants were consistently different in height, leaf length/width ratio, flower size, and frequency of hyperstyly when compared to normal plants. The reasons for these differences are unknown, but other $\mathrm{T}_{\mathrm{L}}$-DNA genes, possibly rolB, rolC, and rolD, or $T_{R}$-DNA may be responsible for these differences.

The presence of T-DNA sequences in the transgenic plants was confirmed by DNA hybridization analysis of genomic DNA separately for $T_{L}-$ and $T_{R}$-DNA. The genomic DNA was analyzed with both HindIII and EcoRI, although only a representative sample of the results is shown (Fig. 4). In all cases, kanamycin-resistant plants appeared to contain at least one copy of the $T_{L}$-DNA, as indicated by the detection of fragments that comigrated with the fragments from the reconstruction experiment. Internal $T_{L}$-DNA fragments were observed for HindIII fragment 17 in wild type and all mutants except rolC $\mathrm{C}^{-}$ plants, where the rolC mutation disrupts the fragment. Internal frequent HindIII-32 was present in all lines, except one containing rolD- where the fragment was deleted in the Ri plasmid. Likewise, rolB- plants appeared to be missing only HindIII-30a, which is disrupted by the Tn5 insertion. The chimeric kanamycin-resistance gene and the rolA insertions disrupted the HindIII-21 fragment of the wild-type $T_{L}$-DNA and created new fragments of high molecular weight $(11 \mathrm{~kb})$. The high molecular weight of this band and the fact that this fragment comigrates with the related endogenous T-DNA sequences makes analysis of the rolA locus with HindIII difficult. However, the rolA locus was analyzed in some lines with EcoRI, and these data corroborated the evidence with HindIII that each line contains at least one copy of the $\mathrm{T}_{\mathrm{L}}$-DNA. These data demonstrated that the lack of plant abnormalities in the case of rolA- lines are not due to the absence of $T_{L}$-DNA transfer.

The hybridization data also show that all lines contain at least some portion of the $T_{R}-D N A$. The results indicate that some of the lines contain the auxin genes, as indicated by the presence of the fragments in two lines that comigrate with HindIII-15. One of the rolC $\mathrm{C}^{-}$lines (lane 5, Fig. 3B) contains an exceptionally long $T_{R}-D N A$ that extends beyond the normal boundary in the left end of HindII-22. The effect of the auxin genes on the plant morphology is not clear; however, the presence of the severely wrinkled leaf phenotype is not correlated with the presence of the complete $T_{R}-D N A$. For example, the DNA from an R1500 transformed plant did not contain the complete $t m s 1$ region of the $T_{R}$-DNA (lane 2, Fig. 4). This observation is consistent with earlier observations (Durand-Tardif et al. 1985; Taylor et al. 1985b).

\section{Characterization of rolA locus}

Studies performed with $T_{\mathrm{L}}$-DNA mutants indicated that the rolA locus probably controls the severely aberrant plant phenotype. However, whether rolA locus alone controls this plant phenotype or acts in concert with other unidentified genes was not clear. If the phenotype was controlled by the single locus, the introduction of this locus into plants without other $T_{L}$-DNA genes should result in aberrant plants. Genetic studies have shown that the rolA locus spans across the central HindIII site, between HindIII-21 and HindIII-30a fragments, and is defined by the EcoRI site on the left and the BamHI site on the right (Fig. 1; White et al. 1985).

The rolA locus was subcloned as the 2-kb EcoRI/ BamHI fragment into the plant transformation vector pGA472 (An et al. 1985) and named pFP3. The vector pGA472 was derived from the nopaline-type Ti plasmid pTiT37 and does not contain any pRiA4b $T_{L}-D N A$. The vector is capable of autonomous replication in Agrobac-

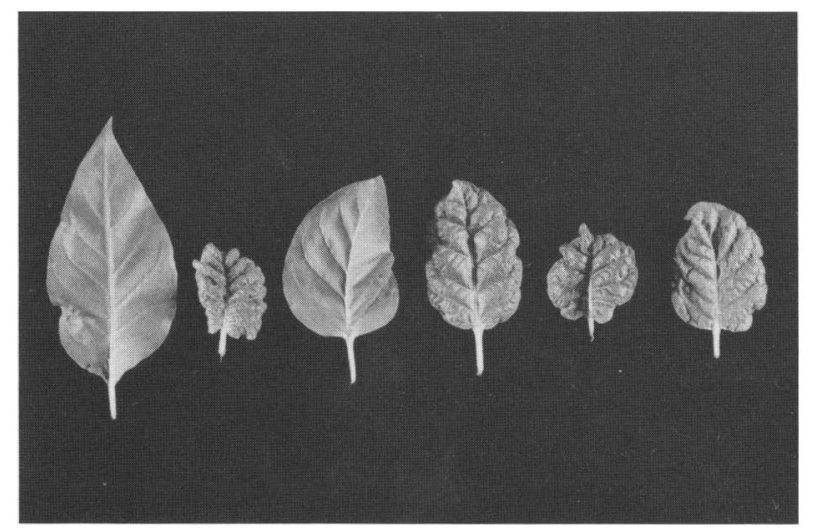

Figure 3. Comparison of leaves of the plants transformed with rol loci mutants. From left: untransformed, R1500 (wild type), R1501 (rolA-), R1502 (rolB-), R1503 (rolC-), R1504 (rolD ${ }^{-}$). 
Table 2. Comparison of transgenic plants

\begin{tabular}{|c|c|c|c|c|c|c|}
\hline & Control & $\mathrm{R} 1500$ & $\operatorname{rolA}^{-}$ & rolB- & rolc- & rolD- \\
\hline Height $(\mathrm{cm})$ & $\begin{array}{l}120 \\
(10)\end{array}$ & $\begin{array}{l}55 \\
(19)\end{array}$ & $\begin{array}{l}92 \\
(12)\end{array}$ & $\begin{array}{l}83 \\
(14)\end{array}$ & $\begin{array}{l}63 \\
(5)\end{array}$ & $\begin{array}{l}77 \\
(6)\end{array}$ \\
\hline Leaf length $/$ width $^{\mathrm{b}}$ & $\begin{array}{c}1.80 \\
(0.08)\end{array}$ & $\begin{array}{c}1.10 \\
(0.20)\end{array}$ & $\begin{array}{c}1.50 \\
(0.15)\end{array}$ & $\begin{array}{c}1.40 \\
|0.13|\end{array}$ & $\begin{array}{c}1.20 \\
(0.07)\end{array}$ & $\begin{array}{c}1.50 \\
(0.13)\end{array}$ \\
\hline Flower size $(\mathrm{cm})$ & $\begin{array}{c}4.10 \\
\{0.06\}\end{array}$ & $\begin{array}{c}3.00 \\
(0.29)\end{array}$ & $\begin{array}{l}3.60 \\
(0.216)\end{array}$ & $\begin{array}{c}3.20 \\
(0.06)\end{array}$ & $\begin{array}{c}3.30 \\
(0.12)\end{array}$ & $\begin{array}{c}3.30 \\
(0.09)\end{array}$ \\
\hline Hyperstyly (\%) & 0 & 70 & $17^{d}$ & 53 & $38^{d}$ & 45 \\
\hline
\end{tabular}

Figures in parentheses indicate standard deviation.

a Maximum distance between two points parallel to the mid-vein of the leaf; 15 leaves per determination.

${ }^{b}$ Maximum distance between two points perpendicular to the mid-vein of the leaf.

c Length of the corolla.

d Some flowers showed shorter style $(>1 \mathrm{~mm}$ ) than the anthers (not considered for hyperstyly measurements).

terium (binary vector) and contains the plant-expressed kanamycin-resistance gene. The plasmid pFP3 was mobilized into the T-DNA-deficient strain of $A$. tumefaciens LBA4404 (Hoekema et al. 1983). Leaf disks of $N$. tabacum were transformed with LBA4404 containing pFP3, and plants were selected on MS104 medium containing $100 \mu \mathrm{g} / \mathrm{ml} \mathrm{kanamycin} \mathrm{(Horsch} \mathrm{et} \mathrm{al.} \mathrm{1985).}$

Plants transformed with pFP3 had the aberrant phenotype similar to $T_{L}$-DNA containing plants /data not shown). The plants were severely stunted as an apparent result of extremely shortened internode distances. The leaf morphology was also extremely altered. The lengthto-width ratio was very low $(0.95)$ compared to that of normal plant leaves, and the leaves were severely wrinkled in appearance.

A T-DNA analysis was performed with total genomic DNA extracted from rolA transgenic plants. A 3.2-kb internal T-DNA fragment extending from one HindIII site

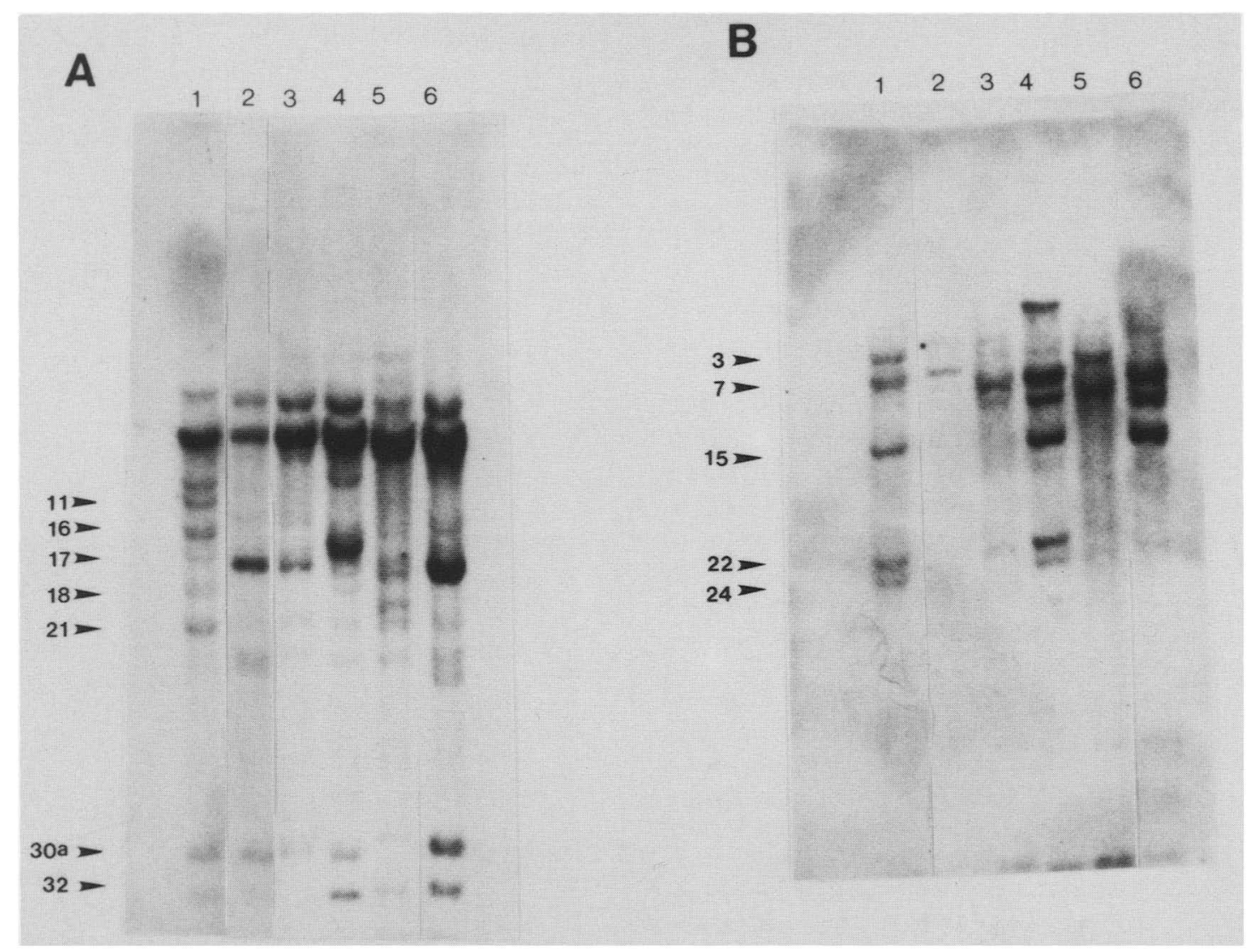

Figure 4. T-DNA analysis of the transgenic plants. DNA isolated from transgenic $N$. tabacum plants was digested with HindIII, separated electrophoretically on gel, transferred to nitrocellulose membranes, and probed with pFW302(A) and pFW41 (B). (Lanes 1$)$ One-copy reconstruction using the Ri plasmid and DNA of untransformed N. tabacum; (lanes 2) transformed with R1500; (lanes 3) transformed with R1504; (lanes 4) transformed with R1503; (lanes 5) transformed with R1502; (lanes 6) transformed with R1501. 
within the rolA locus and a second site within the pGA472 vector was used as evidence for the presence of the rolA region. The plant DNA was digested with $H$ indIII and probed with Ri $T_{L}$-DNA sequences, and the 3.2 $\mathrm{kb}$ fragment was observed in all plants with the aberrant phenotype (Fig. 5).

Because the EcoRI-BamHI fragment alone can cause developmental abnormalities in transgenic plants, the fragment was sequenced to obtain information about gene(s) and their protein product|s). Previous studies have indicated that the carboxyl region of the rolB locus extends to the left of the PstI site present in HindIII-30a, going toward the central HindIII site between HindIII-21 and HindIII-30a (Furner et al. 1986). Hence, the locus (loci) responsible for the aberrant morphology should be situated on the EcoRI-PstI fragment. The DNA sequence of this region showed the longest ORF extending into HindIII-30a from HindIII-21. The ORF is $300 \mathrm{nu}-$ cleotides in length and potentially encodes for a protein of 11,015 daltons (Fig. 6). No significant homology was
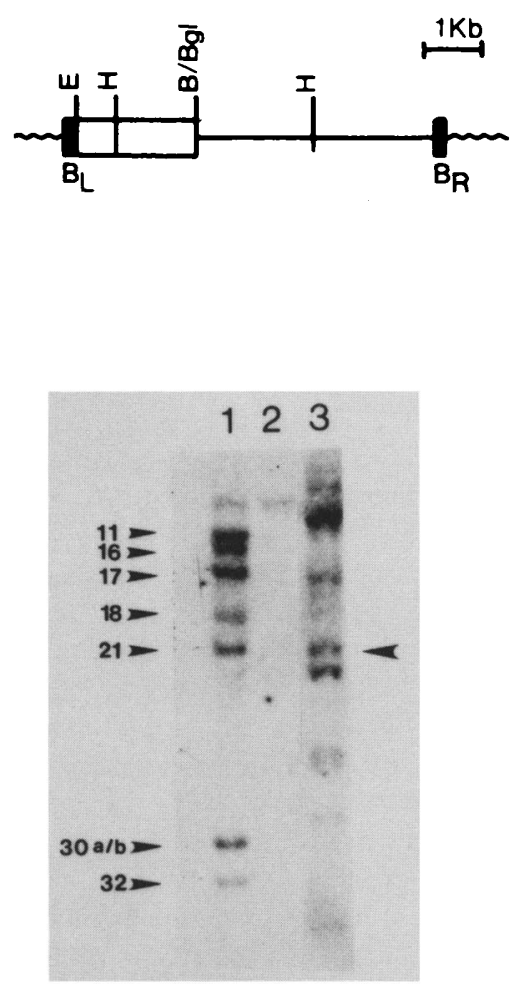

Figure 5. T-DNA analysis of the plants transformed with rolA. DNA isolated from a plant transformed with rolA was digested with HindIII and transferred to nitrocellulose membrane after electrophoretic separation on agarose. The probe used was pFW302. (Top) The restriction map shows the T-DNA of pFP3. $\left(B_{L}\right.$ and $\left.B_{R}\right)$. The left and the right borders respectively, of the T-DNA of the Ti plasmid. The rolA locus [isolated as the EcoRI-BamHI fragment from the Ri plasmid [Fig. 1)] is shown as an open box. The DNA fragment of $3.2-\mathrm{kb}$ expected to hybridize with pFW302 is indicated by an arrow. (Lane 1) Onecopy reconstruction; (lane 2) untransformed N. tabacum; (lane 3) transformed $N$. tabacum with rolA. detected between this rolA protein and other T-DNA or any other gene products. We also mapped the Tn5 insertion in $\mathrm{R} 1058$, the rolA ${ }^{-}$strain, and found that the insertion was indeed within the coding region of the rolA locus (Fig. 6).

\section{Discussion}

The $\mathrm{T}_{\mathrm{L}}$-DNA of the Ri plasmid from $A$. rhizogenes strain A4 has been shown to control several phenotypic behaviors in transgenic plants and primary wound tumors. These results clearly demonstrate the involvement of at least one $\mathrm{T}_{\mathrm{L}}$-DNA locus, namely rolA, in the expression of phenotypic traits in both transgenic plants and primary tumors. rolA had been shown previously to affect the morphology of roots that proliferate from $K$. diagremontiana leaf tumors. $K$. diagremontiana roots induced by strains containing rolA tend to be thicker, more curled, and more stunted than roots induced by a rolA ${ }^{-}$ strain (White et al. 1985). A recent report indicates that rolA may also be able to direct root initiation from tobacco stem explants and leaf disks (Vilaine et al. 1987). rolA alone controls the severely wrinkled leaf morphology of transgenic plants, as demonstrated by the leaf morphology of plants containing the rolA locus without other $T_{L}$-DNA genes. In addition, no severely wrinkled plants were obtained with a $\mathrm{T}_{\mathrm{L}}$-DNA containing a rolA mutation; therefore, no other $T_{L}$-DNA gene appears to be capable of directing the phenotype.

The wrinkled leaf effect is probably not limited to tobacco. Similar results have been obtained with Nicotiana glauca containing the rolA gene (P. Pythoud and V.S. Sinkar, unpubl.), and the wrinkled leaf phenotype has been reported in a range of plants including carrot (D. carota), morning glory (Convolvulus arvensis), tomato (Lycopersicum esculentum), potato (Solanum tuberosum), and Nicotiana plumbaginofolia (Tepfer 1984; Ooms et al. 1985; Peerbolte 1986; Shahin et al. 1986).

The analysis of plants containing individual $T_{L}$-DNA genes is affording a better understanding of the contribution to the seemingly complex and pleiotropic effects of the $\mathrm{Ri} \mathrm{T}_{\mathrm{L}}$-DNA. The severely wrinkled leaf morphology that is controlled by rolA corresponds to the $\mathrm{T}^{\prime}$ phenotype of Tepfer (1984). Individual regenerated plants often display the wrinkled $\left(\mathrm{T}^{\prime}\right)$ phenotype or less severely affected symptoms (T phenotypic plants; Tepfer 1984). The $T^{\prime} / T$ switching has been observed previously with plants containing the complete $T_{L}$-DNA (Tepfer 1984) or plants with rol loci A, B, and C (Spena et al. 1987). These results and the mRNA analysis of revertant plants (Sinkar et al. 1988) indicate that the switching of phenotypes can result from the loss or reduction in the expression of rolA. Loss of the wrinkled plant phenotype correlates with the absence of a rolA-specific transcript (Sinkar et al. 1988). The size of the rolA transcript has been estimated at 650-800 kb (Taylor et al. 1985a; Spena et al. 1987; Sinkar et al. 1988). The fact that plants containing rolA alone can revert to normal suggests that reversion or switching is due to a host plant function that leads to inactivation of the gene. Whether 
ATCATTGCGTAGACTGCATATTGACCGCTCTTTCGGCGCTGGGCCTGCTTTTACTGTTGC CTAGCGTTCGGACAGCCACCAGAGAATGGGCTATATAGATCCTTTCATCAAACCAAAACA TTACTAAGATCATGCTGTAACGCTTCAATACGGTGAGTGTGGTTGTAGGTTCAATTATTA CTATTTTTGAAGCTGTGTATTTCCCTTTTTCTAATATGCACCTATTTCATGTTTCAGAAT $Y$

GGAATTAGCCGGACTAAACGTCGCCGGCATGGCCCAGACCTTCGGAGTATTATCGCTCGT GluLeuAIaGlYLeuAsnVal AlaGlyMetAlaG InThrPheGlyVal LeuSerLeuVaI

CTGTTCTAAGCTTGTTAGGCGTGCAAAGGCCAAGAGGAAGGCCAAACGGGTATCCCCGGC CysSerLys LeuVa IArgArgAl a LySA I LYSArgLYSAl a LysArgVal SerProGlY

CGAACGCGACCATCTTGCTGAGCCAGCCAATCTGAGCACCACTCCTTTGGCCATGACTTC GluArgAspH is LeUAlaGluProAlaAsnLeuSerThrThrProLeuAlaMetThrSer

CCAAGCCCGACCGGGACGTTCAACGACCCGCGAGTTGCTGCGAAGGGACCCTTTGTCGCC GI nAlaArgProGIYArgSerThrThrArgGluLeuLeuArgArgAspProLeuSerPro GGACGTGAAAATTCAGACCTACGGGATTAATACGCATTTCGAAACAAACCTACGGGATTA AspVal LysI leGl nThrTyrGlyI leAsnThrH is PheGluThrAsnLeuArgAsp * * *

ATACGCACGTGGCTGGCGGTCTTCGATTCATTTCCACGCCGGAGATGATATCGAATATGT

TCTGTTAAGTTAAAATAAGCTGCGAGCCATGGCGCGATTGTCCTGTTTTATTAATATAGT

ACTTTAACGTCTCTTTAGAGCGTTTGTGTAATGTCGTGAAAATGTTTTATGTCAAATGTA

Figure 6. Nucleotide sequence of rolA locus. The nucleotide sequence of the relevant part of the EcoRI-PstI fragment is presented (720 bp). Three-letter amino acid code is placed below the codons in the ORF. Putative promoter elements and polyadenylation signal sites are underlined. The site of Tn5 insertion in the rolA mutant used in these studies is indicated by an arrow.

switching is always due to changes in rolA expression is unknown.

The presence of the severely wrinkled and less severe phenotypes when plants contain the complete $\mathrm{T}_{\mathrm{L}}$-DNA, or rolA, rolB, and rolC loci, indicates that other rol genes, particularly rolB and $r o l \mathrm{C}$, also contribute to aspects of the abnormal plant phenotypes. Effects in transgenic plants by other rol loci are also suggested by subtle differences of rol mutant plants. rolA ${ }^{-}$plants were not identical to normal plants in appearance, nor were $\mathrm{rolB}^{-}$and rolD $\mathrm{D}^{-}$identical to complete $\mathrm{T}_{\mathrm{L}}$-DNA plants. However, the nature of the rol mutation plants is such that we cannot confidently assign phenotypes to the other genes. Individual plants varied, depending on the copy number of the T-DNA insert and in the presence of $T_{R}$-DNA sequences. A better assessment of the other genes will come from analyses similar to those using the rolA plants. Studies with transgenic plants containing the other rol genes, either individually or in combination, are in progress, and at least one recent report concerning the effect of another rol locus (rolB) in transgenic plants has appeared. Cardarelli et al. (1987) reported that plants containing the rolB locus have the wrinkled phenotype, although no distinction is made between the $T$ and $T^{\prime}$ phenotype (slightly wrinkled vs. severely wrinkled). In similar experiments, we have observed some minor abnormalities such as leaves with uneven surfaces, increased leaf hairs, reduction in plant height, and floral hyperstyly in plants containing rolB, rolC, or rolD (P. Phythoud, unpubl.). In fact, abnormalities of various degrees were observed in plants containing only vector DNA (pGA472). Culture conditions also appear to affect the less conspicuous plant abnor- malities. A careful evaluation of transgenic plants harboring individual $T_{L}$-DNA genes will shed further light on the contributions of each locus.

Aside from the phenotype of transgenic plants, several recent reports have demonstrated that different rol loci may direct similar plant growth responses. Vilaine et al. (1987) have reported that leaf disks inoculated with strains containing rolA alone produce roots, and these roots behave in an identical fashion to roots harboring the complete $T_{L}$-DNA. Spena et al. (1987) report that either rolA or rolB will induce rooting on tobacco leaf disks, and rolC will induce rooting if provided with the cauliflower mosaic virus ${ }^{35} \mathrm{~S}$ promoter. (These reports did not include descriptions of whole plant regeneration and morphology for the individual genes.) On the other hand, only rolB in combination with the auxin biosynthesis genes was able to induce roots on $K$. diagremontiana leaves (Spena et al. 1987; F. Shaheen and F.F. White, unpubl.). Thus, each rol loci and possibly other genes of the $T_{L}$-DNA (e.g., ORF 13 effects on carrot disks; Cardarelli et al. 1987) appear to perform some biochemical functions which, in certain circumstances, result in alterations of plant growth and differentiation. The visible effects of these alterations appear to vary, depending on the host plant or tissues. The proteins and the associated biochemical activities remain unknown.

Specifically, with regard to the rolA locus, the nucleotide sequence of the region has revealed that the largest ORF corresponds to a polypeptide of 100 amino acid residues and 11,015 daltons. This finding is in complete agreement with the ORF (ORF 10) identified by Slightom et al. (1986). (Slightom et al. reported a potential peptide, 99 amino acids long, although the sequence presented indicated the same 100 -amino-acid protein as in our results.) The sequence of one Tn5 mutant places the insertion within ORF 10 . In addition, as reported previously, an insertion at the HindIII site within ORF 10 resulted in a rolA phenotype. However, smaller ORFs exist within the region of the $T_{L}$-DNA used in these experiments and in the experiments of others, and the possibility that an alternative ORF encodes the rolA function has not been excluded. We have made gene constructions that will demonstrate conclusively which ORFs complement rolA mutations on $K$. diagremontiana leaf inoculations and yield the severely wrinkled leaf morphology in regenerated plants. These experiments are in progress.

The intriguing question remains as to the mode of action of the rolA and other rol loci. Although little is known regarding biochemical properties of Ri-transformed plants compared to normal plants, the phenotypes suggest that the pleiotropic effects involve disturbances in phytohormone signaling. Ri-transformed potato plants have also been reported to have disturbances in cellular electrolyte concentrations (Ooms et al. 1986a). These observations are likely to stem from a common cause because membrane permeability and electrolyte flux are intimately connected with phytohormone flux. The effects of the rol genes and the absence of sequence relatedness to known Ti T-DNA plant oncogenes suggest that the rol-gene functions will repre- 
sent previously undescribed modes of regulation of plant growth and development.

\section{Material and methods}

\section{Bacterial strains and plasmids}

A. rhizogenes and E. coli strains and plasmids used in the study are listed in Table 1. Agrobacterium strains were maintained on AB minimal agar (White et al. 1985), supplied with the appropriate antibiotic when necessary. Antibiotic concentrations used were $100 \mu \mathrm{g} / \mathrm{ml}$ kanamycin (Sigma Chemical Company), $100 \mu \mathrm{g} / \mathrm{ml}$ carbenicillin (Geopen, Pfizer Ltd.), and $100 \mu \mathrm{g} / \mathrm{ml}$ Gentamycin (Sigma). E. coli strains were maintained on L agar, supplemented when appropriate with $100 \mu \mathrm{g} / \mathrm{ml}$ kanamycin, $100 \mu \mathrm{g} / \mathrm{ml}$ carbenicillin, $10 \mu \mathrm{g} / \mathrm{ml}$ tetracycline (Sigma), or 50 $\mu \mathrm{g} / \mathrm{ml}$ nalidixic acid (Sigma).

\section{Bacterial DNA isolation}

E. coli clones were screened for plasmid by the method of Birnboim and Doly (1979). Large amounts of plasmid DNA were prepared by the scaleup of this procedure and purified by cesium chloride-ethidium bromide gradient centrifugation. The ethidium bromide was removed by extraction with $n$-butanol saturated with water, and the DNA was precipitated with two volumes of $70 \%$ ethanol. The Agrobacterium DNA was isolated as described previously (White et al. 1985).

\section{Molecular cloning}

Construction of the suicidal plasmid TnMY903 by cloning a plant kanamycin-resistance cartridge [pNOS-NPTII-poly|A) NOS] obtained from pMON128 (Fraley et al. 1983) into an EcoRI site of a disarmed $\mathrm{Tn} 3$ vector has been described in the text. Cloning of rolA locus into a disarmed Ti plasmid vector, pGA472 (An et al. 1985) has also been described in the text. The restriction fragment of the $T_{L}$-DNA used for the cloning is shown in Figure 1.

\section{Transposon mutagenesis}

Tn3 insertions (carbenicillin resistance) were generated by tetraparental mating, using E. coli $\mathrm{C} 2110\left(\mathrm{polA}^{-}\right)$containing pFW302, E. coli HB101 containing TnMY903, E. coli HB101 containing pRK2073, and E. coli HB101 harboring pSShe (transposes on a plasmid with ColEl replicon; Stachel et al. 1985). Transconjugants were selected on L agar containing carbenicillin and nalidixic acid. Replications of pRK2073, TnMY903, and pSShe are strictly dependent on the polA-gene product. pFW302 containing the Tn3 insertion to the left of the rolA locus in HindIII 21 (pVS1) was selected for homologous recombination with the wild-type and various $\mathrm{Ri}$ plasmid rol mutants.

\section{Bacterial conjugation and homologous recombination}

The mobilizable cosmid (pVS1) was introduced into A. rhizogenes strains by triparental mating procedure, as described by White et al. (1985). The self-conjugal plasmid pPH1JI was introduced into $A$. rhizogenes transconjugant strains to select for homologous recombination, as described previously (White et al. 1985).

\section{DNA sequencing}

Small fragments of the EcoRI-PstI fragment were cloned into M13 and were sequenced by the dideoxy method.
Plant inoculations, tissue propagation, and regeneration

Disks obtained from leaves, between the fourth and sixth position from the apex, were used for the transformation of $N$. $t a$ bacum var. xanthi. The disks were infected with $A$. rhizogenes strains according to the method of Horsch et al. (1985). Roots formed on the disks were excised and were grown on MS- medium containing kanamycin $(250 \mu \mathrm{g} / \mathrm{ml})$. These roots regenerated into plants.

For examining the effect of the rolA locus on the phenotype of the regenerated plants, $N$. tabacum leaf disks were infected with $A$. tumefaciens LBA 4404 (Ooms et al. 1985; a helper strain that provides the vir functions in trans) containing rolA (pFP3). The leaf disks were grown on MS 104 growth medium (Horsch et al. 1985) containing kanamycin $(100 \mu \mathrm{g} / \mathrm{ml})$. Kanamycin-resistant shoots formed from these disks were excised and grown on $\mathrm{MS}^{-}$medium supplemented with kanamycin.

Plant nucleic acid isolation and T-DNA analysis

Plant DNA isolation and T-DNA analysis was performed, as described previously (Sinkar et al. 1988).

\section{Acknowledgments}

We thank Dr. Martin Yanofsky for TnMY903; George Bolton, Harvey Bradshaw, Jr., Roy Kanemoto, Thomas Parsons, Ann Powell, Meir Sheffer, and Srinivasan and Martin Yanofsky for helpful discussion. This work was supported by grants from the American Cancer Society (NP-366A), the National Science Foundation (PCM-8315826), and the United States Department of Agriculture (85-FSTY-9-0141) and Philip Morris, USA. F.P. was supported by a postdoctoral fellowship from the Swiss $\mathrm{Na}$ tional Science Foundation.

\section{References}

Ackermann, C. 1977. Pfanzen aus Agrobacterium rhizogenes Tumoren an Nicotiana tabacum. Plant Sci. Lett. 8:23-30.

An, G., B.D. Watson, S. Stachel, M.P. Gordon, and E.W. Nester. 1985. New cloning vehicles for transformation of higher plants. $E M B O / .4: 277-284$.

Beringer, J.E., J.L. Beynon, A.V. Buchanan-Wollaston, and A.W.B. Johnston. 1978. Transfer of the drug resistance transposon Tn5 to Rhizobium. Nature 276:633-634.

Birnboim, H.C. and J. Doly. 1979. A rapid alkaline extraction procedure for screening recombinant plasmid DNA. Nucleic Acids Res. 7:1513-1523.

Boulanger, F., A. Berkaloff, and F. Richaud. 1986. Identification of hairy root loci in the T-regions of Agrobacterium rhizogenes Ri plasmids. Plant Mol. Biol. 6:271-279.

Cardarelli, M., D. Mariotti, M. Pomponi, L. Spano, I. Capone, and P. Contantino. 1987. Agrobacterium rhizogenes T-DNA capable of inducing hairy root phenotype. Mol. Gen. Genet. 209:475-480.

Cardarelli, M., L. Spano, A. De Paolis, M.L. Mauro, G. Vitali, and P. Costantino. 1985. Identification of the genetic locus responsible for nonpolar root induction by Agrobacterium rhizogenes Ri plasmids. Plant Mol. Biol. 6:271-279.

Chilton, M-D., D.A. Tepfer, A. Petit, C. David, F. Casse-Delbart, and J. Tempe. 1982. Agrobacterium rhizogenes inserts a T-DNA into the genomes of the host plant root cells. $\mathrm{Na}$ ture 295:432-434.

Costantino, P., L. Spano, M. Pomponi, E. Benvenuto, and G. Ancora. 1984. The T-DNA of Agrobacterium rhizogenes is transmitted through meiosis to the progeny of hairy root plants. I. Mol. Appl. Genet. 2:465-470. 
David, C., M-D. Chilton, and J. Tempe. 1984. Conservation of T-DNA in plants regenerated from hairy root cultures. Biotechnology 2:73-76.

De Cleene, M.D. and J. De Ley. 1981. The host range of infectious hairy root. Bot. Rev. 47:147-194.

De Paolis A., M. Mauro, M. Pomponi, M. Cardarelli, L. Spano, and P. Costantino. 1985. Localization of agropine-synthesizing functions in the $T_{R}$ region of the root inducing plasmid of Agrobacterium rhizogenes 1855. Plasmid 13:1-17.

Ditta, G., S. Stanfield, D. Corbin, and D.R. Helinski. 1981. Broad host range DNA cloning system for gram-negative bacteria: Construction of a gene bank of Rhizobium meliloti. Proc. Natl. Acad. Sci. 77:7347-7351.

Durand-Tardif, M., R. Broglie, J. Slightom, and D. Tepfer. 1985. Structure and expression of Ri T-DNA from Agrobacterium rhizogenes in Nicotiana tabacum in phenotypic specificity. I. Mol. Biol. 186:557-564.

Estramareix, C., P. Ratet, F. Boulanger, and F. Richaud. 1986. Multiple mutations in the transferred regions of the Agrobacterium rhizogenes root-inducing plasmids. Plasmid 15:245-247.

Fraley, R.T., S.G. Rogers, R.B. Horsch, P.R. Sanders, J.S. Flick, S.P. Adams, M.L. Bittner, L.A. Brand, C.L. Finkl, J.S. Fry, G.R. Galluppi, S.B. Goldberg, N.L. Hoffmann, and S.C. Woo. 1983. Expression of bacterial genes in plant cells. Proc. Natl. Acad. Sci. 80:4803-4807.

Furner, I.J., G.A. Huffman, R.M. Amasino, D.J. Garfinkel, M.P. Gordon, and E.W. Nester. 1986. An Agrobacterium transformation in the evolution of the genus Nicotiana. Nature 329:422-427.

Hoekema, A., P.R. Hirsh, P.J.J. Hooykaas, and R.A. Schilperoort. 1983. A binary plant vector strategy based on separation of vir- and T-region of the Agrobacterium tumefaciens Ti-plasmid. Nature 303:179-180.

Horsch, R.B., J.E. Fay, N.L. Hoffman, D. Eicholtz, S.G. Rogers, and R.T. Fraley. 1985. A simple and general method for transferring genes into plants. Science 277:1229-1231.

Huffman, G.A., F.F. White, M.P. Gordon, and E.W. Nester. 1984. Hairy-root-inducing plasmid: Physical map and homology to tumor-inducing plasmids. I. Bacteriol. 157:269276.

Jouanin, L. 1984. Restriction map of an agropine-type Ri plasmid and its homologies with $\mathrm{Ti}$ plasmids. Plasmid 12:91-102.

Leong, S.A., G.S. Ditta, and D.R. Helinski. 1982. Heme biosynthesis in Rhizobium. Identification of a cloned gene for $\Delta$ amino levulinic acid synthetase from Rhizobium meliloti. J. Biol. Chem. 257:8724-8730.

Moore, L., G. Warren, and G. Strobel. 1979. Involvement of a plasmid in the hairy root disease of plants caused by Agrobacterium rhizogenes. Plasmid 2:617-626.

Murashige, T. and F. Skoog. 1962. A revised medium for rapid growth and bioassays with tobacco tissue culture. Physiol. Plant 15:473-497.

Offringa, I.A., L.S. Melchers, A.J.G. Regensberg-Tunik, P. Costantino, R.A. Schilperoot, and P.J.J. Hooykaas. 1986. Complementation of Agrobacterium tumefaciens tumor inducing aux mutants by genes from the $T_{R}$-region of the $\mathrm{Ri}$ plasmid of Agrobacterium rhizogenes. Proc. Natl. Acad. Sci. 83:6935-6939.

Ooms, G., J. Atkinson, M.E. Bossen, and R.A. Leigh. 1986a. $T_{L^{-}}$ DNA from Agrobacterium rhizogenes plasmid pRi1855 reduces osomotic pressure in transformed plants grown in vitro. Planta 168:106-112.

Ooms, G., D. Twell, M.E. Bossen, J.H.C. Hoge, and M.M. Bur- rell. 1986b. Developmental regulation of $\mathrm{Ri} \mathrm{T}_{\mathrm{L}}$-DNA gene expression in roots, shoots and tubers of transformed potato (Solanum tuberosum cv. Desiree) Plant Mol. Biol. 6:321330.

Ooms, G., A. Karp, M.M. Burrell, D. Twell, and J. Roberts. 1985. Genetic modification of potato development using $\mathrm{Ri}$ T-DNA. Theor. Appl. Genet. 70:440-446.

Peerbolte, R. 1986. The fate of T-DNA during vegetative and generative propagation--Crown gall and hairy root issues of Nicotiana spp. Ph.D. thesis, Rijksuniversiteit Te Leiden, The Netherlands.

Pythoud, P., V.P. Sinkar, E.W. Nester, and M.P. Gordon. 1987. Increased virulence of Agrobacterium rhizogenes conferred by the vir region of pTiB0542: Application to genetic engineering of poplar. Bio/Technology 86: 584-590.

Shahin, E.A., K. Sukhapinda, R.B. Simpson, and R. Spivey. 1986. Transformation of cultivated tomato by a binary vector in Agrobacterium rhizogenes: Transgenic plants with normal phenotypes harbor binary vector T-DNA, but no Riplasmid T-DNA. Theor. Appl. Genet. 72:770-777.

Sinkar, V.P., F.F. White, and M.P. Gordon. 1987. Molecular biology of Ri-plasmid-A review. J. Biosci. 11:47-57.

Sinkar, V.P., F.F. White, I.J. Furner, M. Abrahamson, F. Pythoud, and M.P. Gordon. 1988. Reversion of aberrant plants transformed with Agrobacterium rhizogenes is associated with the transcriptional inactivation of the $T_{L}$-DNA genes. Plant Physiol. (in press).

Slightom, J.L., M. Durand-Tardif, L. Jouanin, and D. Tepfer. 1986. Nucleotide sequence analysis of $T_{L}$-DNA of Agrobacterium rhizogenes agropine type plasmid: Identification of open-reading frames. J. Biol. Chem. 261:108-121.

Spano, L. and P. Costantino. 1982. Regeneration of plants from callus cultures of roots induced by Agrobacterium rhizogenes on tobacco. Z. Pflanzephisol. 106:87-92.

Spano, L., D. Mariotti, M. Pezzotti, F. Damiani, and S. Arcioni. 1987. Hairy root transformation in alfalfa (Medicago sativa L.). Theor. Appl. Genet. 73:523-530.

Spena, A., T. Schmulling, C. Koncz, and J.S. Schell. 1987. Independent and synergistic activity of rolA, B, and $C$ loci in stimulating abnormal growth in plants. $E M B O T$. 6:38913899.

Stachel, S.E., G. An, C. Flores, and E.W. Nester. 1985. A Tn3 lac $\mathrm{Z}$ transposon for the random generation of $\beta$-galactosidase gene fusion: Application to the analysis of gene expression in Agrobacterium. EMBO J. 4:891-898.

Taylor, B.H., F.F. White, E.W. Nester, and M.P. Gordon. 1985a. Transcription of Agrobacterium rhizogenes A4T-DNA. Mol. Gen. Genet. 201:546-553.

Taylor, B.H., R.M. Amasino, F.F. White, E.W. Nester, and M.P. Gordon. 1985b. T-DNA analysis of plants regenerated from hairy root tumors. Mol. Gen. Genet. 201:554-557.

Tepfer, D. 1984. Transformation of several aspects of higher plants by Agrobacterium rhizogenes: Sexual transmission of the transformed genotype and phenotype. Cell 37:959-967.

Trulson, A.J., R.B. Simpson, and E.A. Shahin. 1986. Transformation of cucumber (Cucumis sativus L.) plants with Agrobacterium rhizogenes. Theor. Appl. Genet. 73:11-15.

Vilaine, F. and F. Casse-Delbart. 1987. Independent induction of transformed roots by the $T_{L}$ and $T_{R}$ regions of the $\mathrm{Ri}$ plasmid of the agropine type Agrobacterium rhizogenes. Mol. Gen. Genet. 206:17-23.

Vilaine, F., C. Charbonnier, and F. Casse-Delbart. 1987. Further insight concerning the $\mathrm{T}_{\mathrm{L}}$ region of the Ri plasmid of Agrobacterium rhizogenes strain A4: Transfer of a $1.9-\mathrm{Kb}$ fragment is sufficient to induce transformation roots on tobacco leaf fragments. Mol. Gen. Genet. 210:111-115. 
White, F.F. and E.W. Nester. 1980. Relationship of plasmids responsible for hairy root and crown gall tumorigenicity. $J$. Bacteriol. 144:710-720.

White, F.F. and V.P. Sinkar. 1987. Molecular analysis of root induction by Agrobacterium rhizogenes. In Plant DNA infectious agents, Plant gene research, (ed. T. Hohn and J. Schell), vol. 4; pp. 149-177. Springer Verlag Wien Press, Berlin.

White, F.F., G. Ghidossi, M.P. Gordon, and E.W. Nester. 1982. Tumor induction by Agrobacterium rhizogenes involves the transfer of plasmid DNA to the plant genome. Proc. Natl. Acad. Sci. 79:3193-3197.

White, F.F., B.H. Taylor, G.A. Huffman, M.P. Gordon, and E.W. Nester. 1985. Molecular and genetic analysis of the transferred DNA regions of the root-inducing plasmid of Agrobacterium rhizogenes. J. Bacteriol. 164:33-44.

Willmitzer, L., J. Sanchez-Serrano, E. Busfeld, and J. Schell. 1982. DNA from Agrobacterium rhizogenes is transferred to and expressed in axenic hairy root plant tissues. Mol. Gen. Genet. 186:16-22. 


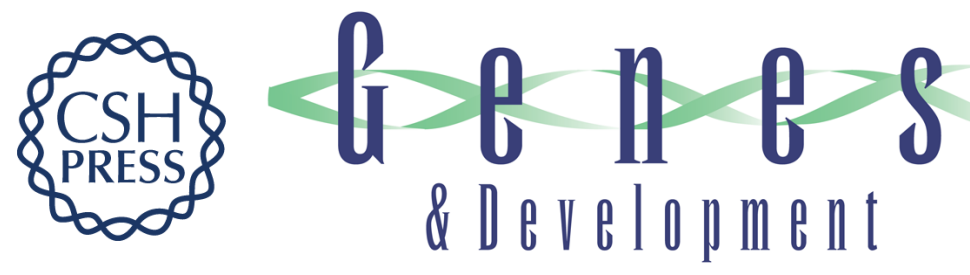

\section{rolA locus of the $\mathrm{Ri}$ plasmid directs developmental abnormalities in transgenic tobacco plants.}

V P Sinkar, F Pythoud, F F White, et al.

Genes Dev. 1988, 2:

Access the most recent version at doi:10.1101/gad.2.6.688

References This article cites 46 articles, 8 of which can be accessed free at: http://genesdev.cshlp.org/content/2/6/688.full.html\#ref-list-1

License

Email Alerting

Service

Receive free email alerts when new articles cite this article - sign up in the box at the top right corner of the article or click here.

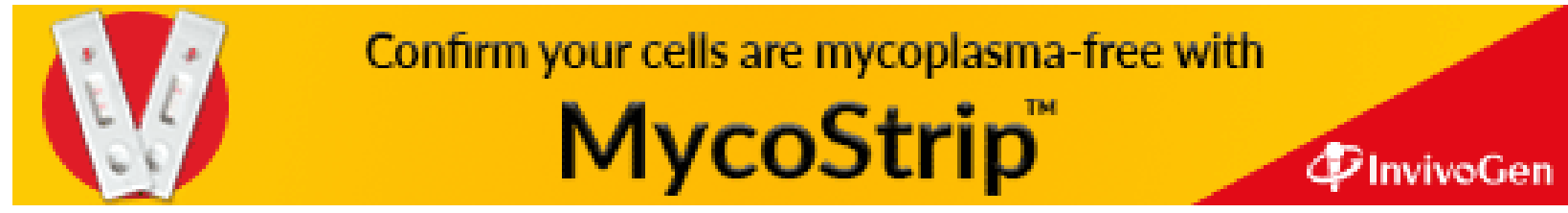

